\title{
THE IMPORTANCE OF CONTENT IN BUSINESS COMMUNICATION: EXPLORATION OF SMES WEBSITES PROTOCOLED WITH ESTGA- UA
}

\author{
D. Baptista, S. Estrela \\ University of Aveiro (PORTUGAL)
}

\begin{abstract}
The importance that the content acquires on the Web requires in the business context an increasing investment in hiring professionals who know well the paradigm of the digital reader. This reader is more and more demanding and informed, he does not waste time reading very extensive and descriptive information and, therefore, he focuses mainly on the titles and subheadings, the numbers, the keywords and the first paragraph. However, he let himself be conquered by stories that excite and help him solve his problems.
\end{abstract}

The story that best positions and attracts the consumer attention is the history of the company. People like to know the history of the company. So often, when a consumer chooses a brand to consume, he chooses it because of the entrepreneurial company/brand history, the challenges it faced, the mistakes it made and above all, what it did to achieve the victory.

The present study is part of a research in which the data were obtained through the administration of an online questionnaire survey to a sample $(N=89)$ of SMEs protocoled with the School of Technology and Management of Águeda - University of Aveiro (ESTGA-UA), in Portugal, within the scope of the curricular internships of the Degree in Retail Management and the Higher Education Training Course (TESP) in Small and Medium Enterprises (SME) Management.

In the first part of the study, a diagnosis was made that allowed to know the reality and to draw the digital picture of these companies in three dimensions: to identify the social media used and the importance attributed to it; to know whether SMEs have a strategy for managing and producing digital content; and to identify the profile of the person responsible for the production/management of these contents.

From this diagnosis it is concluded that SMEs, although they value and use social media to communicate, do not have a defined communication strategy, mainly due to the lack of human resources with specific training. In addition, it was also concluded that SMEs give great prominence to the platform of social interaction Facebook, although they consider the Website the most important digital platform. Based on this conclusion and on the studies that recognize the Website as the most important platform for the digital communication strategy (because it presents itself as a "gateway" to the company through search engine searches and allows to direct the users to the other channels of communication) we analyze the website of all the companies surveyed who identifies themselves and consider the website very important.

It is intended to understand how the page that tells the story of the company and/or shows it can attract and thrill the audience while at the same time if it is able to create value to the brand.

Keywords: ESTGA-UA, Social Media, Website, Digital Content, Business Communication, SMEs.

\section{INTRODUCTION}

Technology changed the way we communicate and the way we interact with each other, and allowed the enterprises to communicate directly with their consumers through the share of relevant differentiating contents, which meet consumers' needs and captivate them.

The magazine The Furrow, created in 1895 by the enterprise Deer \& Company, should have been the first one to work is what is known by Content Marketing. The purpose of this publication was to help and to instruct the farmers, making them more informed, to increase their professional activity $[1, p$. 23].

The company can use the different channels it has at its disposal to made available content about herself, its products and services, as the brand's official blog, as personal blogs and social networks. 
However, the literature highlights the importance that the website has in the first contact with the potential customer, because it is a platform that aggregates information and a gateway to other communication channels as, for instance, the Social Media. The present article, inserted in an ongoing work, whose data already presented allowed to draw the digital picture of a sample of 89 SMEs protocoled with the Águeda School of Technology and Management - University of Aveiro (ESTGAUA), in Portugal, aims to understand if the companies' websites have relevant and useful contents for those who access them and which elements are made available about their story, foundation, business activity and products/services; and if the companies' websites provide the access to their social media.

\section{LITERATURE REVIEW}

The founder of Content Marketing Institute, Pulizzy [2, p. 5], considers that "the marketing and business process for creating and distributing valuable and compelling content to attract, acquire, and engage a clearly defined and understood target audience - with the objective of driving profitable customer action." More important than obtaining the immediate sales' growth, the Content Marketing is a long-term strategy, which allows to build a relation of trust through a brand's positive image. This way, Pulizzy [2, p. 5] relying on Maksymiw, defines the Marketing Content as "the process of developing and sharing relevant, valuable, and engaging content to a target audience with the goal of acquiring new customers or increasing business from existing customers". Content Marketing is "relevant" and "valuable" [3] but demands "Content Strategy plans for the creation, publication, and governance of useful, usable content" [4] and the share of contents through an integration strategy of different communication channels. According to Lieb and Owyang [5], the effectiveness of content coverage is the result of the Converged Media of three channels of communication: owned, earned and pay media, as shown in the Fig. 1.

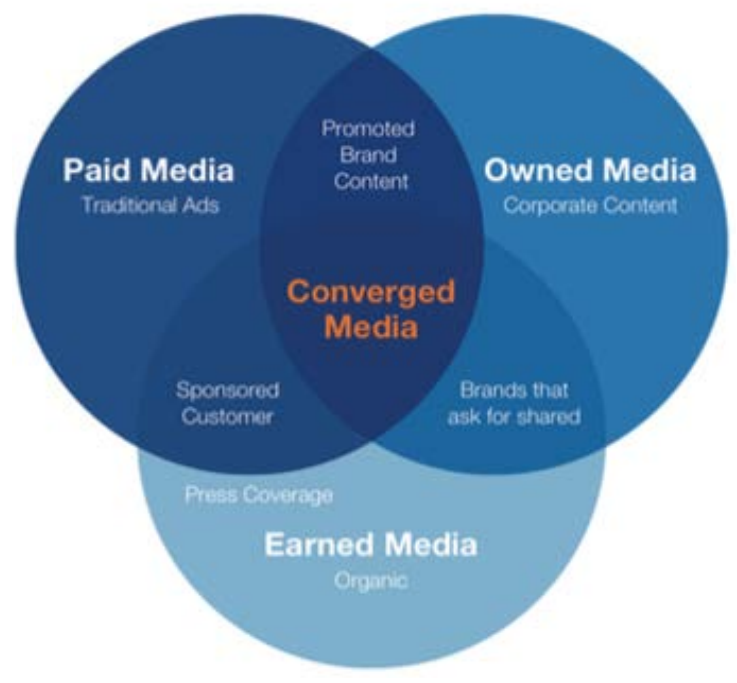

Fig. 1. The Convergence of Paid, Owned \& Earned Media (Source:http://www.webstrategist.com/blog/2013/05/15/video-converged-media-integrating-your-paid-owned-and-earned/)

The owned media includes the channels of communication that the company possesses or totally controls (websites, blogs and social nets as Facebook, Twitter, YouTube...), and in which shares the contents that allow to build relations with their clients; the earned media implies the presence of the company in non-controlled channels, because the content only results through the creation and/or the share of contents through their users (tweets, comments, videos, photos, open online communities or references in communication channels which are made by the company's Public Relations); the paid media is made by paid channels (banners, Pay By Click, search ads, sponsors, sponsored links, payper-post blogging), used by the companies to advertise their products and their services and to reinforce their presence among the consumers.

The inherent costs of the paid media and the impossibility of controlling the share contents through the earned media reinforce the importance that the companies shall give to the owned media, because they can assume the control of the message just by being money-free and they ensure the desired positioning. Even, in the case of the Social Media, it is possible that these channels integrate 
sponsored contents and that the control may not be total, as consumers may react and share their opinions directly in the comments. This reinforces the media's convergence and the presence of overlapping circles of paid, owned and earned, and justifies the option of Dietrich [6] in distinguishing four channels instead of three: the earned, the paid, the owned and the shared (Fig. 2), in which it stands out the social media, that benefit the share of contents through their organic range, although its range is greater if it is paid.

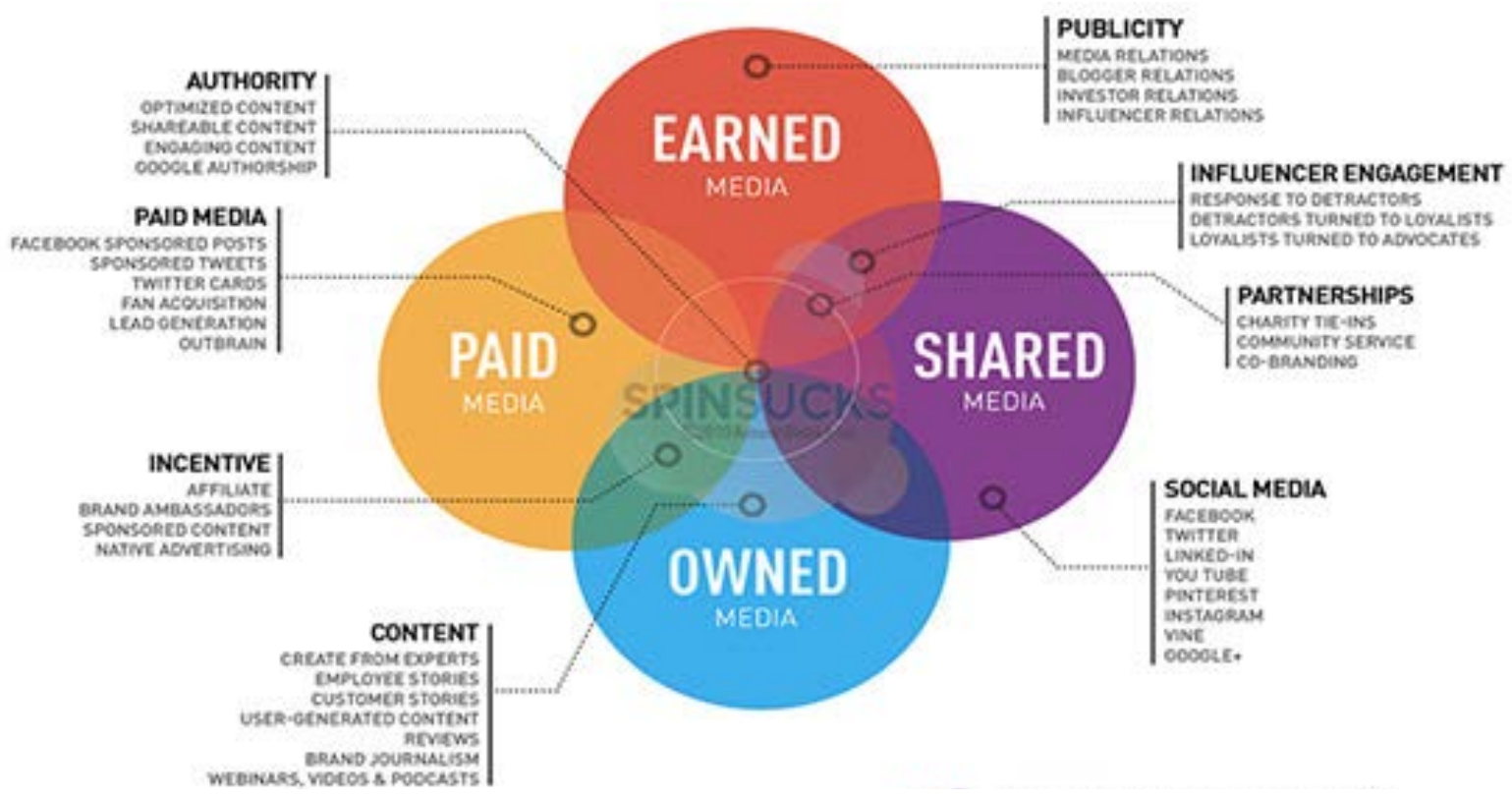

Fig. 2. Gini Dietrich (Source: http://spinsucks.com/communication/pr-pros-must-embrace-the-peso-model/)

According to Otero [7, p. 735], the Social Media are a "vehicle to improve rankings on search engines". According to this author, the bigger is the stake in social media and more the relevance/appeal of the information posted on a firm's social media, "the more it improves the firm's search engine rank", and "the more likely it is to be shared with other consumers". Besides, "this in turn escalates the number of followers, contributes to increased visits to the firm's website, and leads to even higher search engine rankings" [7, p. 735].

Through the owned media, the company has the possibility of giving more visibility to the company's institutional contents, organized and produced in the optics of the client to obtain information in a simple and direct way about a product/service which he seeks, with no extra costs. We are talking about the corporative content, usually shared on the website, a "basis of a platform used in the digital communication strategy that is the 'key to [its] entire business' "[8], which, as usually characteristic in the internet, allows to obtain information on experience attributes before purchase $[9, p .58]$ to visit "the informational website partially substitute for making trips to the offline store" [10, p. 3] and directs the consumers to the other channels of communication [11].

Nowadays, Kushwaha and Venkatesh, cited by Lahuerta Otero, Muñoz Gallego, and Pratt [7, p. 739], the "consumers have become multichannel shoppers, navigating alternative channels through different phases of the purchase process". And even in the case that the "consumers rely on the sales team of an offline store more than they trust a website", "a firm online presence thus becomes a powerful instrument, capable of attracting consumers to a store creating the possibility of a future purchase" and "the better the firm's chances are of attracting revenues from consumers seeking to purchase offline as well [7, p. 731], which justifies the phenomena known by ROPO (Research Online, Purchase Online).

The integration of an online shop in an informative website is an advantage, because it powers and strengthens the sale online and offline. This demands the inclusion of call-to-action, which directs the clients to actions that allow the purchase and the access to promotions, to special packages or to draws. Even, in the case of the small and medium-sized enterprises, often the scarcity or resources difficult the existence of an integrated strategy and demands the investment in simpler and more accessible strategies that increase the enterprises' online visibility. This implies betting on the search engine optimization (SEO) and the search on the backlinks that contribute to the "process of affecting visibility in search engines" and "creating profiles on the most visited social networks" [7, p. 731]. 
Besides, on the website "firms can describe new product arrivals, sector trends, financing options, aftersales service, users' opinions and other valuable information for both current and prospective consumers" [7, p. 731]. The website functions as "an appealing showcase where consumers can find what they want" [7, p. 735], with the advantage of being open 24 hours a day, 365 days a year, to reduce time and travel costs, according to Pawels et al. [10, p. 5], relying on authors as Mathwick, Rigdon; Ratchford, Lee and Talukdar, and to enable a more efficient decision-making. And the "customers who visit the website more frequently are more likely to be exposed to its (product) information and online communications" [10, p. 5] and the company can achieve a bigger range and have more visibility than in a physical store. The higher quality a website has, "greater your effectiveness in consumer attraction. This will ultimately increase the likelihood of a final purchase at your store" [7, p. 734].

About the contents, they must be as the decoration and mannequins in stores, which attract visitors to look at the physical showcase and shall give a positive image of a company and their products/services" [12, p. 268] and show the best we can find "inside" the store.

Basically, it is essential that the website has a self-page, in which we find information about the story of the company and must have information about its foundations and the founders, its occupation area, its principal services/products, as general data (localization and contacts). The experience, the mission, values and point of view help to complement the company's knowledge and the reference to conquests, distinctions and prizes, as well as testimonials and news are information that add value and credit to the company. Besides, the possibility that the client has to search those information in the website, allows the company through the observation of navigation patters or through the filling of forms and/or through questionnaires, to obtain certain "clues" which may be used later by the company to offer products that meet the needs of customers. The registry that the client may do giving his/her email and the permission to send his/her information, allows the company to create an important mailing list for later subsequent sending of newsletters or e-mail-marketing. For this reason, it is important that the website allows the sending of a message to obtain more information or to subscribe a newsletter or simply to activate the subscription of the newsletter.

Other essential concepts in a website are the usage of storytelling techniques to create stories that stay in the memory and that captivate the client, resort to testimony, to prizes or other ways of external validation, instead of self-praise and to use real photos (of the team and of the enterprise's installations) and not to use photos from picture banks to introduce the company, the team, the services and the products are also essential concepts in a website. This way, it will be easier to introduce the company, its services and products, to create a link with its customers, based on trust and to boost conversions and sales.

Thus, "achieving visibility is only possible if the firm's website is well designed. Websites must provide updated, rich, and valuable information presented in a simple, usable, error-free way" [7, p. 733]. The building of a site is a process that demands creativity, knowledge and control of the principal existing codes to the construction of pages totally answerable, that is to say, it should automatically adequate to the different users' devices, in order "to be highly ranked and easily accessible by customers" [7, $p$. 731].

A well-elaborated site must provide an excellent access experiment to the user, whether in the functional aspect, as well in the visual aspect, and shall respect the ten principles of use that guarantee the website to be usable and functional, from the point of view of the users' necessities and the context in which they live [13]. The degree of usability of a website determines its success, that is, the certainty that the user finds whatever he/she seeks.

Once the guaranteed visibility through easy navigability is done, it is equally fundamental that the company defines a strategy of creation of effective and up-to-date content, because "consumers will be less likely to revisit a website if the information is not updated" [7, p. 733].

An important element is a website which is often overlooked is the Page About Us or Our Story content, that may be so unique as its label, its products and its own life story. The consumer likes to know the entrepreneurial history of the company/label to know the challenges it faces, the errors it committed or the failures that have surpassed and what has it done (and what has been doing) to reach the victory [14, p. 937]. For this reason, the first story the company must tell is the company's own story. Stern [15] identified three necessary elements of a story: chronology (has an internal temporality); causality (an initial event results in a response by a character, actions are undertaken to achieve goals, and these actions result in an outcome) and character development (the consumer perceives the state of mind of the story's protagonist, understanding what he/she thinks and/or feels. 
Thus, according to Denning [16, p. 42], "there is no single right way to tell a story: Narrative - also known as storytelling - includes an array of tools, each suitable to a different business". The author distinguishes eight objectives and considers that the story that counts is determinant to persuade and to lead to actions. For instance, "a story that communicates a complex idea and springs people into action - is positive in tone. Such stories are usually very brief and talk about a change that has already happened" and "using a story with negative tonality will generally fail to spark action" [16, p. 42].

A story is a "natural way of human communication" [17, p. 35] and one of the oldest and most powerful modes of communication [18], whose power of persuasion is superior to an artillery of evidence, data, testimonials or arguments [19]. The term defines itself as an understanding strategy and of interaction among the different individuals, which airs, to foster the creation of fictional narratives and the promotion of new ways of understand real events [20].

In the organizational context, the technique of storytelling allows the analysis of the memory [21]. Moreover, the creation of the memory is more than a chronological data set, products' launch dates or even prizes won. It is a mainly narrative strategy [22] able to identify the company's evolution and performance [23]. It functions as a means of transmitting messages and feedbacks and as a stimulus that makes the development of activities that make sense for the whole organization [24]. The narrated stories have the capacity to strengthen the content transmitted, making them more emotive and easy to memorize, and therefore, more effective in retaining consumers [25]. For this reason, today, many companies almost do not speak about the brand or about the quality of their products, but prefer to tell a good story, thus establishing a more affective relationship with their clients [20, p. 591]. This change is understandable because, according to Ramzy [25, p. 53] "the people don't buy products, but the stories that these products represent". As they also do not buy brands, but the myths and archetypes that those brands symbolize". In this way, although companies offer products and services, what consumers are buying will not be exactly what a brand sells, but how it sells and how it can make you dream and believe in dreams, as the traditional children's tales used to do [20, p. 591]. It is in this narrative technique that the words are essential to tell stories, the usage of images is also very appealing, as it promotes the dialogue with the consumer and allows him/her a greater involvement with that particular product. In addition, some contents produced with the use of the graphic visual representation, the infographics, captivate the reading. The way of organizing the information helps the assimilation of information more complex [14].

\section{METHODOLOGY}

The purpose of this essay is to do an exploratory study regarding the content of the website of 28 SMEs that identified themselves in the survey applied to a sample of 89 SMEs protocoled with ESTGA within the scope of the curricular internships of the Degree in Retail Management and the Higher Education Training Course in SME Management. This essay is a continuation of a larger study about digital communication in SMEs [11].

The websites were reviewed between 21 and 28 of January of 2019. The companies whose websites are analyzed are not identified. This analysis examine the content of the website and aims to assess in what way:

1 Does the website has all the information that allows visitors know it and contact its (history, year of foundation, founders, Business activity, products and services, location and contacts and the possibility of sending a message or clarifying doubts through chat)?

2 The website has content that allows adding value to the brand/company/ products/services?

3 The website presents itself as a gateway to social media? When was the last update of Facebook?

To check if the sample of companies $(\mathrm{N}=28)$ have links to social networks from the website and check the latest update dates of the content on Facebook page all the websites were analyzed on Thursday, the 24th of January of 2019. To check if these companies make updates in the weekend, another analysis was made again on Monday the 28th of January of 2019. 


\section{RESULTS}

\subsection{Does the website have enough information to know the company and to contact it?}

Table 1 presents the elements that the website of the 28 SMEs analyzed makes available to visitors and that allows them to know the company, namely its history and information regarding the foundation and the founders; business activity and services / products.

None of the websites lists the five elements taken into account for the analysis. In 11 websites are presented the three elements: Foundation year; business activity; products/services, showing more complete information, but on the other hand, 2 companies only provide information about business activity, 4 about their history, 2 about the founder and 1 about their products/ services.

Overall, the focus is on the business activity and its products / services and Business activity. Although the highlight in these 2 elements only $19(67,9 \%)$ websites present photography gallery/portfolio.

Table 1. Items about companies

\begin{tabular}{l|l|l}
\hline \hline \multicolumn{1}{c|}{ Elements } & \multicolumn{1}{c}{ Frequency } & \multicolumn{1}{c}{$\%$} \\
\hline Foundation year; business activity; products/services & 11 & 39.3 \\
\hline Business activity; products/services & 5 & 19.9 \\
\hline Foundation year; business activity; & 3 & 10.7 \\
\hline History; Foundation year; business activity; products/services & 4 & 14.3 \\
\hline Foundation year; founder; business activity; products/services & 2 & 7.1 \\
\hline Business activity & 2 & 7.1 \\
\hline Products/services & 1 & 3.6 \\
\hline Total & 28 & 100 \\
\hline \hline
\end{tabular}

The presentation of the mission, vision and values helps website's visitors to know the company. However, 12 (42,9\%) of the websites analyzed do not refer to any of these elements. 11 companies $(39,3 \%)$ mention the Mission, vision and values; $2(7,1 \%)$ indicate only the mission, the same number as those that indicate the values; and $1(3,6 \%)$ presents the mission and values.

When analyzing the contents related to the location and contacts made available by the companies on its website, we find that $4(14,3 \%)$ did not provide the map where the company is localized; in the remaining 24 websites we have the contacts and the map with the location of the company.

It is important that the website offers the possibility to the visitors to contact the company and to obtain more information or clarifying doubts about the company and their products/services. In 24 of the websites, they make possible to make contact with the company directly through a message; 5 offer the possibility to subscribe to the company newsletter and only 1 have chat (Table 2).

Table 2. Ways to contact the company

\begin{tabular}{l|c|c|c}
\hline \hline & $\begin{array}{c}\text { Direct message } \\
\text { contact }\end{array}$ & Newsletter & Not applicable \\
\hline Direct message contact & 20 & & \\
\hline Newsletter & 3 & 2 & \\
\hline Chat & 1 & & 2 \\
\hline Not applicable & & & \\
\hline \hline
\end{tabular}




\subsection{Does the website have information that allows adding value to the brand/ company/ products/services (testimonials and news about the company, prizes, news and product content, namely specifications, photos...)?}

The websites analyzed seem to show that there is no concern about disseminating content that adds value to their brand and products / services, 5 SMEs provide testimonials and 1 share news about the presence of the company in an event. It should be mentioned that the 4 companies that refer to relevant contents that respond to the necessities of costumers, that create traffic and add value to the company. These contents are integrated in the Content Marketing Concept related to the company's activity and one of them has a video with technical specifications and installation of their materials.

\subsection{Does the website present itself as a gateway to social media? When was the last update of Facebook?}

There are 22 companies that present links but only in 19 of them it is possible for visitors to access social network through the website. 10 of them have the icon on the foot of the page without visibility / highlight, in 4 of them the icon is not activated or allows you to share in the chronology of the user the content of the website's page; 5 of them highlight the social networks on the right side at the top of the page, giving its visibility.

The link to Facebook, the most used platform, is in 21 of these websites, but 5 companies have the icon inactive of just let put a link on the page. Facebook is also a platform with more recent updates, although there is a great heterogeneity in its update as can be seen on table 3 .

Table 3. Facebook: Periodicity updates

\begin{tabular}{l|c|c}
\hline \multicolumn{1}{c|}{ Periodicity } & Frequency & $\%$ \\
\hline + than 4 years & 1 & 6,3 \\
\hline + than a year & 1 & 6,3 \\
\hline + than 1 month and - than 2 month & 1 & 6,3 \\
\hline + than 1 week and - than 1 month & 7 & 43,8 \\
\hline + than 1 day and - than 1 week & 3 & 18,8 \\
\hline Less than 24 h & 3 & 18,8 \\
\hline Total & 16 & 100 \\
\hline \hline
\end{tabular}

\section{CONCLUSIONS}

As the literature highlights, the power of the internet it is undeniable and, at the same time, one opportunity that SMEs should take advantage to assert themselves and to be more competitive. Internet and the corporative websites are an important source of information for most consumers to find products and services or to gather valuable information before making a purchase [7]. In order to accomplish this goal it is important that the company's website has a page about itself, in which its history is given and as well as information about the foundation and the founders; the area of operation, the main services / products, as well as general data (location and contacts). Experience, mission values and vision help to complement the company's knowledge and the reference to achievements, distinctions and awards, testimonials and news are information that adds value and gives credibility to the company.

The analysis of the website's content demonstrates that each company made available different elements about itself, its story, product/services, business activity, localization, mission, vision and other information that adds value to the company, brand and products / services. In some cases, the contents are dispersed, laconic, not responsive and incomplete that does not allow or make difficult, to those who visit, to know the company well, and, in other cases, the content do not attract and even discourages the visitor to continue reading the contents of the website (an illustrative example is how one of the companies presents its history: in an extensive and unappealing way that, as written on the website, takes 10 minutes to read. This example shows, at the same time, that the strategy of Storytelling is not applied by the SMEs). 
SMES made available more informative content and, above all, highlight what they do and the products / services they offer. The sample of the companies in sharing relevant and interesting contents that attract and respond to the need of the users of internet is practically non-existent. The use of photographs, in spite of being used, in some cases are from banks of images or of reduced quality, adding little value to the company. This scenario leads us to conclude that companies have a long way to go to take advantage of the potential that digital transformation can being, namely to ensure its visibility, to provide detailed information on its own website, and eventually to lead customers to a final purchase [7].

The case study allowed to conclude that the companies focused use social networks, and in 23 of 28 of them, links to these networks are available from the website. However, the analysis of these links to Facebook indicate that the actualization of the shared contents does not follow the behavior of the users. Regarding the weekend update, it is seen that only one company did an update on the weekend. These data confirm the results already evidenced in the first case study carried on [11].

In the same way it is important to ensure that complete, clear, current, concise and accurate information on the website to empower and attract consumers to the forum, it is an advantage for companies to have their social networking pages updated. It is important to note that social networks have the advantage of being closer to the users; they allow more interaction and generate more traffic, resulting in a greater visibility for the company and a greater projection of its services / products.

\subsection{Limitations and future research}

The study presents some limitations, which are largely related to the sample of websites analyzed (and the websites' content, namely not using the storytelling strategy to tell the story of the company) and that can be overcome by extending the analysis to a larger number of companies.

\section{REFERENCES}

[1] M. V. L. M. Monteiro, "Estratégia digital de marketing de conteúdos: estudo de caso Nestlé Cozinhar, Universidade Católica Portuguesa, 2016.

[2] J. Pulizzi, Epic Content Marketing: How to Tell a Different Story. McGraw-Hill, 2014.

[3] K. Rahim and B. Clemens, "Organizational Goals and Performance Measurement Criteria for Content Marketing," J. Commun. Comput., vol. 9, no. 8, pp. 896-904, 2012.

[4] K. Halvorson, "The Discipline of Content Strategy," Content Strateg., no. 274, 2008.

[5] R. Lieb and J. Owyang, "The Converged Media Imperative: How Brands Must Combine Paid, Owned, and Earned Media," 2012.

[6] G. Dietrich, Spin sucks: communication and reputation management in the digital age. Pearson, 2014.

[7] E. Lahuerta Otero, P. A. Muñoz Gallego, and R. M. E. Pratt, "Click-and-Mortar SMEs: Attracting customers to your website," Bus. Horiz., vol. 57, no. 6, pp. 729-736, 2014.

[8] M. Sheridan, "101 awesome marketing quotes." [Online]. Available: http://cdn2.hubspot.net/ hub/53/ blog/docs/ebooks/101_marketing_quotes_final.pdf). [Accessed: 23-Mar-2013].

[9] P. Huang, N. H. Lurie, S. Mitra, Peng Huang, Nicholas H. Lurie, and S. Mitra, "Searching for Experience on the Web: An Empirical Examination of Consumer Behavior for Search and Experience Goods," J. Mark., vol. 73, no. 2, pp. 55-69, Mar. 2009.

[10] K. Pauwels, P. S. H. Leeflang, M. L. Teerling, and K. R. E. Huizingh, "Does Online Information Drive Offline Revenues?: Only for Specific Products and Consumer Segments!," J. Retail., vol. 87, no. 1, pp. 1-17, 2011.

[11] S. Estrela and D. Baptista, "The use of social media in portuguese companies: empirical study with SMEs protocolated with ESTGA-UA," in 11th annual International Conference of Education, Research and Innovation, 2018.

[12] T. Georgios and D. Theoharis, "Application of modern administration and marketing functions in the dominant Greek companies in food and drink branch," in 5 th International Conference on Contemporary Marketing, 2017, pp. 265-275. 
[13] J. Nielsen, "10 Usability Heuristics for User Interface Design," 1995. [Online]. Available: http://www.nngroup.com/articles/ten-usability-heuristics/.

[14] D. M. da S. Baptista, "A importância do conteúdo na Web: para uma estratégia de comunicação eficaz," in Pelos mares da língua portuguesa III, António Manuel Ferreira, C. Morais, M. F. Brasete, and R. L. Coimbra, Eds. Aveiro: UA Editora, 2017, pp. 925-944.

[15] B. Stern, "Authenticity and the textual persona: postmodern paradoxes in advertising narrative," Int. J. Res. Mark., vol. 11, no. 4, pp. 387-400, 1994.

[16] S. Denning, "Effective storytelling: strategic business narrative techniques," Strateg. Leadersh., vol. 34, no. 1, pp. 42-48, Jan. 2006.

[17] S.-K. Chung, "The International Journal of Arts Education Digital Story telling in Integrated Arts Education," Int. J. Arts Educ., pp. 33-50, 2006.

[18] S. E. Worth, "Storytelling and Narrative Knowing: An Examination of the Epistemic Benefits of Well-Told Stories," J. Aesthetic Educ., vol. 42, no. 3, pp. 42-56, 2008.

[19] B. Kaufman, "Stories that SELL, stories that TELL," J. Bus. Strategy, vol. 24, no. 2, pp. 11-15, Apr. 2003.

[20] D. M. da S. Baptista, "Uma nova perspetiva do conto: o storytelling na estratégia da comunicação empresarial," Forma breve, no. 14, 2017.

[21] D. M. Boje, "Stories if the storytelling organization: a postmodern analysis of Disney 'TamaraLand," Acad. Manag. J., vol. 38, no. 4, pp. 997-1035, Aug. 1995.

[22] D. M. Boje, Storytelling Organizations. London: Sage, 2008.

[23] R. Gill, "Using storytelling to maintain employee loyalty during change," Int. J. Bus. Soc. Sci., vol. 2, no. 15, pp. 23-32, 2011.

[24] M. Marzec, "Titlelling the corporate story: vision into action," J. Bus. Strategy, vol. 28, no. 1, pp. 26-36, 2007.

[25] C. Salmon, Storytelling: la máquina de fabricar historias y formatear las mentes. Peninsula, 2008. 